\title{
'Allowing it to speak out of him': The Heterobiographies of David Malouf, Antonio Tabucchi and Marguerite Yourcenar
}

\author{
LUCIA BOLDRINI
}

\section{NEITHER HISTORICAL NOVEL NOR BIOGRAPHY}

We know very little about the life of Ovid, and it is this absence of fact that has made him useful as the central figure of my narrative and allowed me the liberty of free invention, since what I wanted to write was neither historical novel nor biography, but a fiction with its roots in possible event. ${ }^{\mathrm{I}}$

Thus starts the Afterword of David Malouf's An Imaginary Life, a novel in which the poet Ovid, exiled from Rome, narrates his experience in the border outpost of Tomis, near the delta of the Danube on the Black Sea. 'Relegated' among the Getae at the edges of the Empire and 'expelled from the confines of [the] Latin tongue' (IL p. 26), this glittering and cynical poet undergoes a series of changes or metamorphoses. Initially pining for Rome and its sophisticated, complex language, he learns to overcome his hostility towards the barbarous people and their tongue, but when he discovers a wild Child that had been raised by the wolves in the forest and captures him with the intention of teaching him to speak and to be human, he soon realises that he himself has to learn from the Child another language, based not on symbolization and arbitrary convention but on an intuitive identity with things, on becoming the things signified in silence: 'In imitating the birds, he is not, like our mimics, copying something that is outside him [...]. He is being the bird. He is allowing it to speak out of him' ( $I L$ p. 92); 'my knowing that it is sky, that the stars have names and a history prevents my being the sky. It rains and I say, it rains. It thunders and I say, it thunders. The Child is otherwise. I try to think as he must: I am raining, I am thundering' (IL p. 96). After the death of the village's elderly chief, which the villagers blame on the child's 
demonic powers, the poet and the Child escape across the frozen river. Ovid's death in the grasslands of the north is the poet's final transformation, perhaps a literal metamorphosis like the ones described in Ovid's great poem. Malouf's Afterword concludes: 'My purpose was to make this glib fabulist of "the changes" live out in reality what had been, in his previous existence, merely the occasion for dazzling literary display' ( $I L$ p. I 54$)$.

Is Malouf's novel then a fantasy inspired by 'mere' literary dazzle or, as 'a fiction with its roots in possible event', is it a work that, while not laying claim to the factual accuracy of biography or the broad reliability of the historical background of a historical novel, can however still claim to be rooted in verisimilitude, in events that, although not documented, are nevertheless possible, as would be the case with a realist novel, or in Aristotelian poetics? The Afterword thematizes a tension between the desire to anchor the novel to history and the desire to free Ovid from historical necessity. How can Ovid live out in reality' the metamorphoses to which he is subjected, if metamorphoses are but the occasion for 'literary display'?

I shall come back in the second half of this essay to the question of how the novel and its Afterword construct, or excavate, in the story of Ovid's exile and death, a history of the myth of Ovid and, especially, another history, central not only to this book but to autobiography more generally: that of the concept of man, of what it means to be human. First, however, I want to place An Imaginary Life in the context of other 'autobiografictional' texts and the issues that these raise.

\section{UNDER TRUE PRETENCES}

The tension between historicity and the desire to free the subject from historical necessity also defines, more widely, the large number of novels written as if they were the autobiographies of historical personages, novels that gesture towards historical factuality and literary fictionality, towards 'truth' and invention, and exist under the sign of an essential structural displacement (the 'autobiography' is written by another) that brings to the foreground structural, narrative, and ethical issues also central to autobiography itself.

A list of such fictional autobiographies of historical characters would also include Marguerite Yourcenar's i95 I Mémoires d'Hadrien; ${ }^{2}$ Michael Ondaatje's 198 I The Collected Works of Billy the Kid;3 Peter Carey's 2000 True History of the Kelly Gang, ${ }^{4}$ Manuel Vázquez Montalbán’s 
1992 Autobiografia del general Franco..$^{5}$ I wish to add to this list (and shall explain this apparent anomaly shortly) Antonio Tabucchi's I994 The Last Three Days of Fernando Pessoa, ${ }^{6}$ although this brief narrative of the Portuguese poet's final days and imagined encounter with his heteronyms is written in the third person, thus apparently defying the description of 'fictional autobiography'.

These novels raise a number of issues - first of all, macroscopically, about generic boundaries and generic assumptions. We know they are not autobiographies: they do not advertise themselves as such, we do not expect their authors to be bound by any Lejeunian autobiographical pact; ${ }^{7}$ yet they bring into focus precisely the thinness of the dividing line between the autobiographical (they are written in the first person) and the biographical (they are written by another), between the historical (the protagonists are recognizable individuals who we know to have lived) and the fictional (they exist within texts that are not bound by any duty of fidelity to facts). This raises therefore further questions concerning the nature and status of the subject in and of writing: in the fictional autobiography of a historical character, the grammatical first person becomes the site of an encounter, a stage where the complex relationships between historical, fictional and authorial subjectivities are played out and explored. Central to all this is the issue of the name: its nature, the assumptions that underpin its use and its legal status, the assumptions made about its uniqueness. How can someone - Malouf, Yourcenar, Ondaatje, Vázquez Montalbán - assume the name of another and speak for them? There is something somewhat disturbing and thrilling in this identity theft (would we feel so indulgent if it were our name and identity being thus usurped?). The name carries an authority: the authority to authorise a credit transaction, for example; to sentence someone to exile. What happens to the name and its authority when it is claimed by someone else who can say ' $\mathrm{I}$ ' under false pretences? (But if there is no intention to cheat, are these true pretences?) When the authority taken over is that of an emperor whose word has a performative value, and whose words, once uttered, become law? When the authority taken over is that of someone whose business is to speak fictions, such as that of the poet of Metamorphoses, or of the poet who defines the poet's role as that of being a faker, a pretender? ${ }^{8}$

These are questions fraught with more dangers than meet the I fatal questions perhaps, insofar as they also raise the issues of writing's relation to death, on which Blanchot, Barthes and others since have written so variously and so eloquently, ${ }^{9}$ and of the inextricable link of 
the autobiographical to the thanatographical (this is discussed at length by Ivan Callus in his contribution to this issue of Comparative Critical Studies). I shall come back to writing and death later, but I wish to approach this relationship first from two more limited but related angles, more immediately relevant to the subject matter and structure of the novels that are the focus of this essay, and to the structure of auto/biography.

Ovid, Hadrian, Pessoa write as they approach death - literally approaching it in the case of Hadrian ('Comme le voyageur qui navigue entre les îles de l'Archipel voit la buée lumineuse se lever vers le soir, et découvre peu à peu la ligne du rivage, je commence à apercevoir le profil de ma mort' (OR p. 289; 'Like a traveler sailing the Archipelago who sees the luminous mists lift toward evening, and little by little makes out the shore, I begin to discern the profile of my death', $M H \mathrm{p}$. I6); 'Tâchons d'entrer dans la mort les yeux ouverts...' (OR p. 5 5 5; 'Let us try, if we can, to enter death with open eyes...', $M H$ p. 247)); Billy the Kid in Ondaatje's work may already be dead from the beginning ('These are the killed. [...] (By them) - | Charlie, Tom O'Folliard | Angela D's split arm, | and Pat Garrett | sliced off my head', p. 6). In The Autobiography of General Franco the autobiography of the Spanish dictator can be written by another because Franco is dead.

There is a certain authority (in both the limiting and fully assertive senses of the word 'certain') that comes from death. The words of the dying over the living have a power that comes from their finality, from their approaching the moment when time, already running out, can no longer run out. There is a certain authority that comes from history, the past, what has been and can no longer be changed. It is this authority that these novels exploit, explore and, sometimes, explode.

As to my second point, the structural generic difference between biography and autobiography, it is possible perhaps to encapsulate it as follows: that biography is written by the living subject about an other (preferably a dead other, because death is what allows for the completeness of the biography); and that autobiography is written by the living I about the past but (inevitably) still living self. Autobiography, by its own nature, is always incomplete, because the only autobiographical statement that would complete it, 'I am dead', is the one impossible assertion that cannot be uttered as a literal, autobiographical statement.

The novels I am concerned with in this essay - novels that place themselves and their subjects on the very edge of death - may thus be the only way in which the dead character can 'truthfully', though 
through the agency of another, utter the statement 'I am dead' and achieve the completeness that autobiography is denied but that the subject constantly desires.

\section{DELIRIUM}

Before returning to this desire for completeness and death, I must explain my seemingly inconsistent inclusion of Tabucchi's thirdperson The Last Three Days of Fernando Pessoa within the category of fictional autobiography. It is true of course that autobiographies in the third person, or even autobiographies written as if they were the (auto)biographies of another (such as, notably, Gertrude Stein's The Autobiography of Alice B. Toklas), are not a new phenomenon. But the book poses several problems concerning its genre; in fact, it is unclear what genre it belongs to at all: a very short novel? Novella? Short story? Biographie romancée, as Nabokov's characters would derogatorily call it, ${ }^{\mathrm{IO}}$ but a biography concerned with writing a life only insofar as it turns into writing a death, not so much even a thanatography as, rather, a pathography: the life of a subject in a critical, terminal condition? (Hadrian's life story is also written from the perspective of the final, fatal, malady.) The narrative, divided in three parts corresponding to each of the last three days of Pessoa's life $(28,29$ and 30 November I935), is followed by a note, or appendix, on 'the characters who appear in the book', which gives brief biographical notes about Pessoa, his employer, who accompanied him to the hospital, the barber who shaved him for a last time, and the poet's heteronyms, who visit Pessoa on his sick bed. The best generic description may be the one given by the book's subtitle itself: Un delirio, as if delirium defined the genre to which it belongs, in the same way as some books can be subtitled 'A Biography', 'A Novel', 'A Memoir'. 'Delirium' would presumably be a neighbouring genre to that of the 'Hallucination', the subtitle of another of Tabucchi's works, Requiem. ${ }^{\text {II }}$

The nature of the subject contributes to the uncertainty: Fernando Pessoa, a historical individual and yet a multiple subject who has spoken, historically, in a plurality of voices and personae through his heteronyms, each of them endowed with a biography, style, and corpus of works (and that, of course, is exactly what 'Pessoa' means: persona another twist to the issues arising from the question, what's in another's name?). Can we not then read this auto/biography as if it were written by Pessoa speaking as one of his heteronyms? 'Pessoa chiese una 
pozione di laudano, che era un sonnifero che era abituato a prendere quando, in quanto Bernardo Soares, non riusciva a prendere sonno' (UTG p. I7; 'Pessoa asked for a dose of laudanum, a sedative he used to take when, as Bernardo Soares, he couldn't get to sleep', LTD p. 95). 'In quanto Bernardo Soares' - as Bernardo Soares, qua Bernardo Soares, insofar as Bernardo Soares; this game of pretending to pretend ('O poeta é um fingidor', as Tabucchi loves to quote) opens up the possibility that Tabucchi himself is figured, in the book and through the book, as one of Pessoa's heteronymic voices: The Last Three Days of Fernando Pessoa is the book 'I' mrote when, in quanto Antonio Tabucchi - as Antonio Tabucchi, qua Antonio Tabucchi, insofar as Antonio Tabucchi - I mrote the biography of my own death. It is then possible to describe The Last Three Days of Fernando Pessoa: A Delirium by Antonio Tabucchi as Pessoa's heterobiography of himself as Antonio Tabucchi. (Tabucchi has recently published a collection of articles and reflections on his works, under the title Autobiografie altrui, translatable as Autobiographies of Others or, perhaps, even Heterobiographies. ${ }^{{ }^{2}}$ )

Delirium: a violent mental excitement, from the Latin delirare, deviate from a straight line, from the furrow, whence to deviate, to become deranged, crazy or delirious; from de + lira, ridge between furrows. ${ }^{\mathrm{I}} 3$ Heterobiography: the speaking in another's name under true pretences, the wandering out of one's identity into another's. A kind of lucid madness, a delirium, a working outside or beyond the furrows of reason is at the centre of these works. Pessoa, within the delirium that is his Last Three Days, acknowledges his own biographical delirium. To his heteronym Alberto Caeiro, he says:

Le dirò, caro Caeiro, rispose, il fatto è che io avevo bisogno di una guida e di un coagulante, non so se mi faccio capire, altrimenti la mia vita sarebbe andata in frantumi, grazie a lei ho trovato una coesione. (UTG p. 25)

I will tell you, dear Caeiro, he replied. The fact is that I needed a guide and a coagulant - I don't know if I am making myself clear - otherwise my life would have shattered into pieces. Thanks to you I found cohesion. (LTD p. Iо I)

Pessoa, in other words, found cohesion in splitting himself into multiple personae. In the last section of the narrative, another heteronym, Antonio Mora, visits the poet: they first met at the sanatorium where Pessoa himself was a patient, and Mora taught him about the plurality of the self. Pessoa lived constantly on the verge of madness; his grandmother Dionísia had predicted that madness would be his destiny: 
Pessoa [...] sentiva la voce di sua nonna Dionísia che era morta in manicomio. Fernando, gli diceva sua nonna, tu sarai come me, perché buon sangue non mente, e per tutta la vita avrai me per compagnia, perché la vita è una follia e tu saprai come vivere la follia. (UTG pp. I $5^{-16}$ )

Pessoa [...] heard the voice of his grandmother Dionísia, who had died in a madhouse. Fernando, his grandmother said to him, you will be like me, because blood will tell, and all your life you will have me for company because life is madness and you will know how to live in this madness. (LTD p. 94)

Yourcenar's Hadrian also often refers to his delirium (for example, $O R$ p. 399; $M H$ p. I27), his moments of madness or of non-reason, or of expansion of the mind to include non-rational, non-logical thinking (for example, $O R$, p. 306, p. 427; $M H$ p. 33, p. I 57). The writer herself describes writing the novel as the development of 'une méthode de délire qui n'intéresserait que les insensés' ('Carnets de notes de Mémoires d'Hadrien', OR p. 526; 'A method akin to controlled delirium, of interest, probably, to none but madmen', 'Reflections on the Composition of Memoirs of Hadrian', $M H$ p. 275). Delirium as a method: being taken out of oneself, but participating in the other consciously and intentionally. Yourcenar qualifies her statement and in particular the term 'delirium': 'Encore ce dernier mot fait-il la part trop belle au romantisme: parlons plutôt d'une participation constante, et la plus clairvoyante possible, à ce qui fut' ('Carnets', $O R$ p. 526; 'And yet this term delirium smacks too much of romanticism; let us say, rather, a constant participation, as intensely aware as possible, in that which has been', 'Reflections', $M H$ p. 275). ${ }^{\mathrm{I}}{ }^{4}$ The qualification is important: what is rejected is the Romantic idea of genius and inspiration, and also, implicitly, of an automatic writing that bypasses the consciousness of the artist. Yourcenar's 'delirium' coincides with the clear-sighted participation in another mind, world and time, echoing Hadrian's own ideal of uniting knowledge, participation and sympathy to overcome the limits of the self in a bid to approach immortality (OR p. 29I; $M H$ p. I 8$)$.

The desire to work within and yet deviate from the tracks of history in a kind of 'controlled delirium' is also echoed in the Afterword to $A n$ Imaginary Life:

It was partly to break into a field of more open possibilities that I set my narrative in a remote place about which almost nothing is known, and in an age, the dawn of the Christian era, in which mysterious forces were felt to be at work and thinking had not yet settled into a rational mode. (IL p. I 54, my emphases)

A similar moment of historical suspension, 'the cusp [...] between two cycles of time, the millennium of the old gods [...] and a new era' $(I L$ 
p. I9) - or, in this case, a lull, a pause between different epochs - is evoked by Yourcenar through a remark made by Flaubert: 'Les dieux n'étant plus, et le Christ n'étant pas encore, il y a eu, de Ciceron à Marc Aurèle, un moment unique où l'homme seul a été' ('Carnets', OR p. 5I9; 'Just when the gods had ceased to be and the Christ had not yet come, there was a unique moment in history, between Cicero and Marcus Aurelius, when man stood alone', 'Reflections', $M H \mathrm{p}$. 269). In a later interview, Yourcenar explained: 'The Memoirs of Hadrian could only have been set in a moment of history when things looked relatively bleak, a period of exhaustion - the exhaustion of the ancient world figures prominently in the book - and yet a period when it was still possible to believe that things would continue the same way for some time to come. Fifty years later and it would have been too late, fifty years earlier and it would have been too soon: people wouldn't have been aware of how fragile things were.' ${ }^{\text {'5 }}$ The space for the clearsighted exploration of the subject - a subject hinged to history and yet (especially in An Imaginary Life) freed from it in the workings of the imagination - is given in the moment that expands the rational and suspends, or freezes, the historical; it is the moment when 'thinking [has] not yet settled into a rational mode', a moment of fragility and solitude when 'man [stands] alone', between an epoch already concluded and one not yet begun: a moment that remains anchored to a precise historical juncture and yet is outside, or between, the parallel tracks of history, and whose exploration is a historical delirium through the voice of another in a genre caught, perhaps torn, between opposing forces.

\section{BETWEEN SOCRATES, NARCISSUS, AND ECHO}

One step further from Berkeley's 'esse est percipi' and engaging the fundamental question of autobiography, Gertrude Stein's much quoted words, 'I am I because my little dog knows me' ${ }^{16}$ reverse the Cartesian foundation of identity in self-knowledge ('I think therefore I am'), and, in locating self-knowledge instead outside the self and outside modern rational discourse, anticipate Derrida's notion of 'otobiography' in which the signatory of the autobiographical discourse is not the self but the other: 'it is the ear of the other that signs. The ear of the other says me to me and constitutes the autos of my autobiography.' ${ }^{\text {I7 }}$

The location of the aurobiographical in the other also underpins the heterobiographies that are the focus of this essay. Yourcenar describes 
Mémoires d'Hadrien as 'portrait d'une voix', 'the portrait of a voice' ('Carnets', $O R$ p. 527; 'Reflections', $M H$ p. 275). The phrase is also used to describe the novel Alexis, and it is in this version that it is quoted and appropriated by Antonio Tabucchi: 'Comme tout récit à la première personne, Alexis est le portrait d'une voix ${ }^{\text {I } 8}$ ). Indeed, the eye and the voice are central to Tabucchi's heterobiographical work. In The Last Three Days of Fernando Pessoa, the Portuguese poet tells his heteronym Alberto Caeiro: 'Sì, confermò Pessoa, però per me lei è stato un occhio e una voce, un occhio che descrive, una voce che insegna ai discepoli, come Milarepa o Socrate' (UTG pp. 24-5; 'Yes, Pessoa agreed, but for me you were an eye and a voice, an eye that describes, a voice that teaches disciples, like Milarepa or Socrates', $L T D$ p. гог). The self that risks breaking into a myriad fragments the multiplicity of Pessoa and of the modern self - is saved from complete fragmentation and death by two masters who act, traditionally, as teachers and, here, as coagulants, gluing agents of the self, but whose teachings are radically different: a mystic who learned to change his body into any shape and to conquer his own self, and a teacher of the rational, whose main principles included the imperatives to know oneself and to live life in preparation for death. But the 'eye' and the 'voice' also evoke another story: the tale of Echo and Narcissus.

In Ovid's Metamorphoses, Tiresias answers Liriope's question as to whether her son Narcissus would live a long life with the prophetic but obscure reply that he will live, as long as he does not come to know himself ('Si se non noverit'). ${ }^{19}$ Narcissus - whose fate is the agony of unrequited desire that leads him to distraction from the moment he gazes upon himself, and the agony of unrequitable desire that leads him to destruction from the moment he recognizes himself in the face of the beloved - must be denied self-knowledge if he is to live and be sane.

Autobiography, whose project is founded on self-speculation and in the desire for self-possession, is defined by a tension: on the one hand, the Socratic philosophical imperative 'Know Thyself'; on the other, the prohibition to know oneself, the curse of Narcissus. Because of Narcissus, the Socratic requirement can never be fully achieved; because of Socrates, the drama of Narcissus cannot be fully played out. Indeed the tension between Socrates and Narcissus must be preserved: tipping the balance one way or another leads to death, whether by hemlock or by daffodil.

It could in fact be argued that autobiography, the reflection of and on the self, reverses the fate of Narcissus: whereas the youth's recognition 
of himself - iste ego sum (1. 463) - leads him to derangement and eventually death, as the prophet had warned, the recognition of oneself as oneself - I am that one, iste ego sum - is the precondition of the success of the autobiographical project. However, the temporal distance that determines the autobiographical - I write now of myself then - prevents this simultaneous specular identity. The temporal denial of self-identity is indeed already implicit in the 're-' of recognition, which doubles up the Socratic imperative for self-cognition into a repetition of the same as other. If for Narcissus the repetition of the visual image is always simultaneous, for Echo the structure of repetition implies, and is determined by, temporal distance. The drama of the autobiographical thus trebles up and is played out between Socrates, Narcissus and Echo, and indeed it is the latter that appears to give it meaning: if repeating the words of others is her punishment, Echo nevertheless manages to turn this affliction to advantage, giving new meanings to the words she repeats by lending voice to her desire. 'Huc coeamus', says Narcissus, 'let us meet here'; but Echo's 'coeamus', confirming her desire to meet, also expresses her desire for a sexual encounter. When Narcissus rejects her - 'emoriar, quam sit tibi copia nostri' ('I would die before I'd let you touch me', 'give you power over me', 'give you enjoyment of me') - his words are countered by Echo's desire, 'sit tibi copia nostri' ('I would give you power over me', 'I would have you touch me', 'I would give you enjoyment of me'). ${ }^{20}$ Echo's predicament, and not only Narcissus's, can thus also be taken to allegorize the condition of autobiography, whose meaning is determined not (or at least not only) by the past, but by the structure imposed through the present narrative. Autobiography is caught between parallel and constantly diverging tracks or furrows, working within, but permanently diverging from them: then and now; selfhood and otherness; simultaneity of speculation and temporality of re-signification. Oscillating between history and literature, autobiography is also caught between the mythical and the philosophical. By their evocation of this interplay between Socrates, Narcissus and Echo, fictional autobiographies of historical characters, or heterobiographies, bring to the fore what is also true of autobiography: that the resolution of the autobiographical dilemma comes not through the desire to say 'I know myself' and 'I am that one', but by the ability to say 'I am all those ones'.

Yet the split between self and other, subject and object that originates in the moment of self-reflection and that is inherent in any autobiographical act (and which doubles the moment in the development of the 
subject that Lacan has called the mirror stage), engenders a desire - by definition unachievable - to re-unify the subject and recompose the fissure between self and world (a desire to recover that original presymbolic - or, in Kristeva's terms, semiotic - state). The regression to the original moment of plenitude and self-sufficiency when language and self-consciousness were not yet present, however, can only be realised through death, when language is lost and conscious self-speculation can no longer take place. The paradox is that, while desiring to transcend its own divisions, the autobiographical subject also desires to experience this renewed state of plenitude consciously. This desire may be one of the prime reasons for the consistent location of the 'heterobiographical' subject on the edge of death, and, indeed, for the appeal of the genre itself. It is this impossibility that is dramatized in the narrative and thematic structure of An Imaginary Life, and it is therefore to this novel that I now wish to return in some more detail.

\section{CONFLICTING NARRATIVES}

At the end of the novel, Ovid and the Child have crossed the Danube and are walking through the steppes of the north:

And so we come to it, the place. I have taken my last step [...]. From here I ascend, or lower myself, grain by grain, into the hands of the gods. It is [...] the point on the earth's surface where I disappear. (IL p. I 50$)$

I described earlier the dynamic tension between historicity and fictionality that drives the novel, and I would like to come back to what Malouf calls 'a fiction with its roots in possible event' (Afterword, $I L$ p. I 53). 'Roots' is the operative word here, evoking - as it inevitably does when we are dealing with the poet of the Metamorphoses - the transformations of characters into trees, plants, flowers that Ovid described, and in particular perhaps evoking Daphne, whose metamorphosis into the laurel symbolic of poetic glory suggests a fitting end for Ovid. 'Roots' could thus be therefore what the Roman poet develops in reaching 'the place', the 'point on the earth's surface' where his flight from Tomis ends, and he becomes one with/in the earth.

Such a reading of Ovid's death as a final and literal metamorphosis seems to be encouraged by David Malouf's assertion in the Afterword that he wanted to make Ovid 'live out in reality' - with all the ambiguities we have seen to be implied in this expression - the 'changes' to which he had subjected his characters in his work ( $I L$ p. I54). Yet 
there is nothing in the text itself that requires such reading: Ovid, tired from the escape and the harsh walk over frozen terrain, could simply and naturally lie on the ground and pass away at this point, returning to the earth in the universal and eternal cycle of transformation of matter. Thus 'roots' carries a dual and somewhat contradictory reading: taken literally, it suggests the literary dazzle of metamorphosis; taken figuratively, it describes a more 'realistic' natural death. It is Malouf's / Ovid's metaphoric and metamorphic poetic language that generates such double readings. A particularly significant example of this can be found right at the end of the novel, when the Child drops 'useless pebbles that where they strike the ground suddenly flare up as butterflies' (IL p. I 52). John Stephens, observing that at the end of $A n$ Imaginary Life 'figuration becomes particularly problematic', asks: 'Does the sun strike the fallen pebbles so that they send up reflected light which might be compared on the one hand to a sudden fire and on the other to sunshine on the wings of butterflies, or do the stones fall, change into butterflies, and fly up again?' Stephens's conclusion that, at the end, 'metamorphosis may turn out to be no more than a trick of language' and that 'the narrator [...] may once again have become the victim of language' seems to me, however, to miss a central point. ${ }^{21}$ Of course the metamorphosis is a trick of language (we are reading a book, after all, and poems were Ovid's trade) - but so would be the realism of a natural death in this fictional account. The issue is not one of mutually exclusive alternatives of which one is truer than another, but of the coexistence of conflicting but equally valid narrative alternatives; to regard Ovid simply as the victim of a linguistic trick would be to disregard both his desire to return to a state of plenitude and the similar unachievable desire to overcome the split between self and world inherent in any autobiographical project.

Ovid's disappearance into the earth at 'the dawn of the Christian era, in which mysterious forces were felt to be at work' (Afterword, $I L$ p. I54) may also call up another kind of historical grounding: a third, conflicting narrative of Ovid's life and death and his returning to the earth that involves (anachronistically and yet appropriately to the historical moment from which Christianity was born), an echo of the Christian burial service, 'earth to earth, ashes to ashes, dust to dust'. Yet again, the Afterword takes up a suggestion already present in the main text, where Ovid, echoing Yeats's 'The Second Coming', introduces himself: 'I am the poet Ovid - born on the cusp [...] between two cycles of time, the millennium of the old gods, that shudders to its 
end, and a new era that will come to its crisis at some far point in the future I can barely conceive of' (IL p. I9). In this context, the wild child captured by Ovid and the villagers during a hunt in the woods, whose footprints had been sighted in previous years, seen by the villagers as a portent or a demon and whom Ovid wishes to make human, may put us in mind of another Child who was living at this particular moment in history, a Child at once human and divine whose advent will bring the old gods and their Empire to an end, and whose 'new era' will 'come to its crisis' in a future which is made to coincide with our time ('in the future I can barely conceive of, and where you, reader, sit in a lighted room', Ovid continues in the sentence just quoted, directly placing us in this time of crisis). This feral Child, always spelt with the capital C, whose main teaching to Ovid is silence, may thus, paradoxically, also evoke the incarnation of the Word.

The interplay between the narrative's and the Afterword's complex ambiguities thus frames the existence of Ovid's 'Imaginary Life' within these unresolved poles, both within and outside history, transcending it and yet immanent to it, pure dazzling imagination and yet historically determined.

If the historical conjuncture is precise and yet mysterious, so is the geographical location, a place 'about which almost nothing is known' (Afterword $I L$ p. I54) but which we can exactly pinpoint to the Getic village of Tomis, on the Black Sea, now the modern Romanian city of Constanta. Bridging geography and history, the Afterword also locates Ovid in a changing but clear trajectory of literary / historical interpretations and successive re-appropriations of his life and works, symptomatic of the Western fascination with the figure, work and fate of the poet. Malouf describes how, in the Middle Ages,

Ovid became a popular figure of mythology and the search for his grave resulted in the veneration of several legendary but spurious sites, some of them as far from his original place of exile as central Hungary. [...] To the Renaissance reader Ovid was the most modern of the Latin poets. (IL p. I54)

The 'place' where Ovid disappears (IL p. I50) is the place where he keeps reappearing in the posthumous imagination as the subject of myth. Malouf's subjection of Ovid to the dazzle of his own fables thus continues the tradition of appropriation and mythification of the Roman poet, a lineage in which Malouf also inscribes himself. At the same time, in its very structure of coexisting and conflicting narratives, 
in the multiple meanings elicited through the metaphoric and metamorphic duplicity of its language, and in the interplay between 'Ovid's' story and the author's Afterword, with its explicit references to different epochs (the dawn of the Christian era, the Middle Ages, the Renaissance, the eighteenth- and nineteenth-century debates on the Child of Nature, modern times), An Imaginary Life suggests the need for a process of tracing back through these many layers the roots of such myths and inscriptions. The polysemic nature of the text has indeed led to a plurality of critical readings that would affiliate it with (or engage it in a dialogue with) a number of different literaryhistorical categories. As a text especially concerned with the relationship between language and identity and almost explicitly invoking Saussurian and Lacanian theories of language through its extended reflection on signs, referents, signifiers and signifieds - and a trajectory, Ovid's, that could be described in terms of overcoming the mediation of the Symbolic for an encounter with (or a return to) the Real, with which the Imaginary finally coincides $^{22}$ - the novel can be seen to share concerns central to much postmodernist literature. In thematizing the plight of the writer who, at the edge of the Empire and away from its metropolitan centre, needs to find a new language and a new model of autonomous subjectivity, An Imaginary Life proposes itself as a quintessentially Australian, or postcolonial, novel, although some accuse the novel of betraying the postcolonial condition insofar as its resolution (Ovid's final passivity and his desire to go beyond language and beyond the human) does not offer any viable political postcolonial position, the dissolution of subjectivity that Ovid embraces at the end representing the denial of an autonomous, coherent and solid identity for the postcolonial subject. ${ }^{23}$ Modernism's simultaneous emphasis on exile and dispossession and on the imaginative transcendence of differences exists alongside a (romantic and modernist) primitivism that seeks in less developed cultures the authenticity lost by a dehumanising modernity, but the novel can also be interpreted as a post-colonial reply to other modernist responses to the primitive: in the wilderness of Australia, Richard Somers, the protagonist of D. H. Lawrence's Kangaroo (I923),

understood now that the Romans had preferred death to exile. He could sympathize now with Ovid on the Danube, hungering for Rome and blind to the land around him, blind to the savages. So Somers felt blind to Australia, and blind to the uncouth Australians. To him they were barbarians [...]. He surveyed them from an immense distance, with a kind of horror. ${ }^{24}$ 
Whether intentionally or coincidentally, ${ }^{25}$ Malouf's novel 'writes back' to Lawrence's vision of Australia by making the exiled Latin poet undergo a transformation that reveals the 'raw life' of the 'savages' around him to be closer to the 'unity of things' and allowing Ovid to see the world 'differently' and feel himself 'loosen and flow again' (IL p. 65). An Imaginary Life also inscribes itself within the Romantic tradition, in its thematizing of the desire to overcome the breach between Man and Nature in an encompassing integration; echoes of Emerson, of Wordsworth's 'Tintern Abbey', 'Intimations of Immortality' and The Prelude have all been traced. ${ }^{26}$ But Malouf's novel also engages other historical, literary and philosophical debates that precede the Romantic and post-Romantic concerns just outlined. The Afterword identifies a key source for his story of a wild child brought back into the human community:

The encounter with the Child, which makes up the main part of this book, has no basis in fact, but I have verified my description from the best account we have of such a phenomenon, J.M.G. Itard's painstaking observations of Victor, the wild boy of Aveyron, which no writer on the subject can ignore. (IL p. I54)

The story of Itard's attempt to educate the wild boy he called Victor is well documented, and Malouf's references to it are often very precise. ${ }^{27}$ Also important, 'growing as it does out of the eighteenth century' (Afterword, $I L$ p. I 54), is the place of Itard within the debate on the state of nature, the natural man, and what constitutes the essence of being human. Rousseau and Condillac were the central figures of the debate (Itard was a follower of the latter and a critic of the former), but going back through the eighteenth century, whose context Malouf invokes, one would have to take note of other interventions, such as Defoe's I 726 Mere Nature Delineated; Or, a Body mithout a Soul (a treatise containing his observations on the wild boy Peter of Hanover, who was brought into English society and became an object both of general curiosity and of learned discussion on what makes humans human, on the relationship between man and nature, between the primitive and civilization); and, going further back, Montaigne's essays, in particular 'On the Cannibals' and its discussion of the Noble Savage in the context of other imperial and colonial expansions. ${ }^{28}$ (Montaigne, in turn, brings the discussion back to Greek and Roman sources, including Herodotus, who would have been one of the referents of the Latin world for the understanding of the nature of the barbarous people of the north among whom Ovid finds himself in 
his exile, and who provides Malouf with information about the Scythians (Afterword, $I L$ p. I53)). Key for most participants in this philosophical debate is the role of language in the definition of the human, insofar as language is the highest expression of a rationality conferred by the soul and distinguishing man from brute. Malouf's novel, with its multiple and conflicting narratives, can thus also be read as a meditation on and dramatization of what constitutes the essence of the human, the place of language and the ability for linguistic self-expression within such definition, the issue of language being of course also central to autobiography, at least since Augustine ${ }^{29}$ and to man's self-definition as an individual.

This framework, placing the investigation into the nature of the human at the centre of the novel, shows that the layers of literary and philosophical references in An Imaginary Life are essential to the construction of Ovid as a subject, and their 'excavation' (as in an archaeological process) central to the novel's investigation of the (autobiographical) subject. Thus, alongside the many allusions to Romantic poetry identified by critics, I would argue that the novel also evokes another key Romantic text, Mary Shelley's Frankenstein, which also engages with Rousseau's theories of the relationships between man and nature, language and education. ${ }^{30}$ Distinct parallels can be found in the escape north, among the 'floating sheets of ice' that surround Walton's ship and his groaning companions in Frankenstein ( $F$ pp. I2I3) and over 'the groaning, the cracking, the grinding' of the 'ice floes' of An Imaginary Life ( $I L$ p. I37); in the winter, which 'has been dreadfully severe' - 'but the spring promises well' ( $F$ p. I I $)$, just like in An Imaginary Life, where the frozen winter is followed by the 'signs of spring', 'everywhere about us' (IL p. I43); in the sense of expectation with which Walton anticipates going to 'unexplored regions, to "the land of mist and snow"' ( $F$ p. I I ), or with which Ovid and the Child cross into the unknown world north of the Danube - a land so unexplored that Ovid even doubts its existence ( $I L$ pp. I37-8); in the travelling breeze, 'warm with the first breath of spring' (IL p. I43), that 'fills' Walton 'with delight' $(F$ p. 7$)$ as much as it does Ovid and the Child, left 'glorying at last' in the open freedom of the empty landscape (IL p. I4I) 'stretched out in every direction' $\left(F_{\mathbf{I} 3}\right)$; in particular, in the foregrounding of the conflicting relationship between nature and culture, of the question of the state of nature and the natural man - a question that centres, for Ovid / Malouf on the Child, and for Frankenstein / Shelley on 'the creature': 'innocent' beings who 
would learn human language in order to be admitted to the company of human beings, but who ultimately fail to bridge the gap that separates them from the human community - with much more sinister and malevolent consequences in Frankenstein than in An Imaginary Life, but in both cases at the cost of the death of other human beings. Both An Imaginary Life and Frankenstein are in sum explorations of the limits of human nature, the boundary between culture and nature, and what lies on either side of that boundary. Both are stories of the search for the origin of life and for the original man; of man's ascent and regression up and down the ladder of being ( $I L$ pp. 74, 95), and of the failure of civilization to look upon man in the original state of nature and accept it for what it is - which is also the failure of civilization to look upon itself and accept itself for what it is.

\section{UTOPIA}

David Malouf's imaginary life of Ovid, the poet of metamorphoses and of myth, is thus also a quest for origins and originality (the story of the Child raised by the wolves recalling the origins of Rome and of the wolf-children Romulus and Remus), and the novel inscribes itself within this long-running historical philosophical and literary debate on the definition of man in his relation with nature and with the idea of nature. Yet for Rousseau the state of nature is not a real, historical, original condition but a hypothetical one - nor, indeed, is it that ideal either. When men live in isolation and have no social bonds or feelings, they experience neither happiness nor sadness; when their relationships are motivated purely by the physical need to survive and perpetuate the species - to eat, to drink, to mate - they are no longer all that distinguishable from beasts. The ability to satisfy every desire and need allows for peaceful living, but in this condition man has no (and no need of any) morals. Men become really human only from the moment they employ their rational faculties, form societies and develop a language of communication and exchange..$^{31}$ As it is also in Condillac, Defoe, Montaigne, full humanity is inextricably linked with the acquisition of language. Ovid intuitively knows this when he connects the Child's ability to speak a human word in the delirium of his fever with the proof of the Child's final belonging to the human (IL p. I 8 ). Yet it is silence that Ovid finally seeks, a silence that abolishes human language in the name of a desire for that nostalgic, utopian, and ultimately only imaginary ideal of complete naturalness. 
This 'true language' consists of the 'speech in silence' of infancy, a language 'whose every syllable is a gesture of reconciliation' and of continuity with the thing signified (IL pp. 96-8), beyond symbolization and representation, without mediation. It is a language that, impossibly, would allow the journey back through the mirror stage, beyond the moment of self-speculation that inaugurated both the acquisition of language and the autobiographical act. The desire for total originality meets the desire for total finality; the desire for absolute transcendence of the divisions imposed by language and culture coincides with a desire for absolute immanence in nature. Yet this can only be a selfannihilating desire, because the return by choice to the original natural state is impossible: the natural state, as Rousseau also knew, has literally no place for the human: returning to it is as utopian as the desire consciously to experience one's own death, or return to the prelinguistic, semiotic state of infancy. The voyage back through the mirror - the return to the state of non-division - can only be achieved in death, 'earth to earth, dust to dust, ashes to ashes', in the metamorphosis into an element of the natural landscape, in the annihilation of self and/or self consciousness. The desire to bypass the self-speculation of the autobiographical can only resolve in the thanatographical ('I know what it is we are looking for. It is the grave of the poet Ovid - Publius Ovidius Naso, Roman of the equestrian order, poet,' $I L$ p. I8). The 'place' reached by Ovid at the end is a literal u-topia, a place that only exists in the myths that our culture constantly constructs and that philosophical investigations build on, giving them body, but whose layers philosophical and literary investigations constantly peel off again. The conclusion of Ovid's journey mirrors, and dramatizes, the conclusion of heterobiography, driven by the desire to become the other without mediation, annulling the difference that separates subject from object, the self from the world, bypassing the temporal split that separates the writing I from the written I in order to be whole, and yet maintain the self-consciousness that would enable the subject to live through death.

It is the utopia that makes Hadrian bid, at the end, 'Let us try, if we can, to enter into death with open eyes...'

\section{NOTES}

I David Malouf, An Imaginary Life (New York: Braziller, I978), p. I 53 (hereafter $I L)$.

2 Marguerite Yourcenar, Mémoires d'Hadrien, in Euvres romanesques (Bibliothèque 
de la Pléiade, Paris: Gallimard, I982), hereafter OR. English translation (hereafter MH): Memoirs of Hadrian (Harmondsworth: Penguin, I986).

3 Michael Ondaatje, The Collected Works of Billy the Kid: Left Handed Poems (London: Picador, I989).

4 London: Faber, 200I.

5 Barcelona: Planeta, I992.

6 Antonio Tabucchi, Gli ultimi tre giorni di Fernando Pessoa: Un delirio (Palermo: Sellerio, 1994), hereafter UTG. English translation in Dreams of Dreams and The Last Three Days of Fernando Pessoa: A Delirium (San Francisco: City Lights, I999), hereafter $L T D$.

7 Cf. Philippe Lejeune, Le pacte autobiographique (Paris: Seuil, I975).

8 'O poeta é um fingidor. | Finge tão completamente | Que chega a fingir que é dor | A dor que deveras sente', writes Pessoa in 'Autopsicografia' (Poesias, vol. I of Obras Completas de Fernando Pessoa (Lisbon: Ática, I978), p. 237), lines I-4, which can be translated as, 'The poet is a faker [a pretender]. He pretends so completely that he even pretends that the pain he really feels is pain [he fakes he is suffering the pain really he really feels]'.

9 See, for example, Maurice Blanchot's The Writing of the Disaster (Lincoln: University of Nebraska Press, I986), and Roland Barthes's I968 'The Death of the Author', in Image - Music - Text (London: Fontana, I977), pp. I42-8.

Io 'You know those idiotic "biographies romancées" where Byron is coolly slipped a dream extracted from one of his own poems?' says Fyodor in The Gift (London: Penguin, I963), p. I84; in The Real Life of Sebastian Knight they are called 'by far the worst kind of literature yet invented' (London: Penguin, I964), p. I7.

I I Requiem: un'allucinazione (Milano: Feltrinelli, I992), original Portuguese edition, Requiem: uma alucinação (Lisbon: Quetzal, I99I).

I2 Autobiografie altrui: Poetiche a posteriori (Milano: Feltrinelli, 2003).

I3 The Oxford Dictionary of English Etymology, ed. by C. T. Onions (Oxford: Oxford University Press, I966); Ernest Klein, A Comprehensive Etymological Dictionary of the English Language (Amsterdam: Elsevier, 1971).

I4 Yourcenar also describes as 'hallucination' the sense caught by Piranesi, inspired by Hadrian's mourning for Antinous, in his engravings of a Viem of Hadrian's Villa ('Carnets', OR pp. 522-3; 'Reflections', $M H$ p. 270).

I5 Marguerite Yourcenar, With Open Eyes: Conversations with Matthieu Galey, translated by Arthur Goldhammer (Boston: Beacon Press, I984), p. 4I. The passage continues, 'What the frame gives you is a precise location of a moment in the past; it's because of this ability to locate the moment precisely that lessons drawn from the study of the past still have validity for us', With Open Eyes, p. 4I. I shall come back to the importance of such 'precise location' - both historically and geographically - later in the essay, with regard to the quest for Ovid's death place in Malouf's novel.

I6 'What Are Masterpieces and Why Are There so Few of Them' (I936), in What Are Masterpieces (Los Angeles: Conference Press, I940), pp. 8I-95 (p. 84).

I7 Jacques Derrida, 'Roundtable on Autobiography', in The Ear of the Other: Otobiography, Transference, Translation (Lincoln and London: University of Nebraska Press, I985), p. 5 I.

I8 Antonio Tabucchi, 'Autobiografie altrui', in Autobiografie Altrui, p. 92. 
I9 Ovid, Metamorphoses, Book III, with introduction, notes and vocabulary by A. A. R. Henderson (Bristol: Bristol Classical Press, I979), 1. 348. Line references to this edition will appear parenthetically in the text.

20 Metamorphoses, III, lines 386-92. On Echo's re-signification of language, see John Brenkman, 'Narcissus in the Text', The Georgia Reviem 30, 2 (I976), 293-327.

2 I John Stephens, “Beyond the Limits of our Speech...”: David Malouf's $A n$ Imaginary Life', Commonmealth Novel in English, 3, 2 (I990), I6o-8 (p. I67).

22 See, for example, Bill Ashcroft, 'The Return of the Native: An Imaginary Life and Remembering Babylon', Commonmealth I6, 2 (I993), 5I-60; Amanda Nettelbeck, 'Imagining the Imaginary in An Imaginary Life', Southern Reviem 26, I (I993), $28-38$.

23 See, for example, Philip Martin, 'Australia in Disguise?', Overland 74 (I979), 596o; Philip Neilsen, Imagined Lives: A Study of David Malouf (Queensland: University of Queensland Press, I990), pp. 4I-2, 57-8 et passim; Karin Hansson, Sheer Edge: Aspects of Identity in David Malouf's Writing (Lund: Lund University Press, I99I), esp. pp. 7-I9; Gareth Griffiths, 'An Imaginary Life: The PostColonial Text as Transformative Representation', Commonmealth I6, 2 (I993), 6I-9; Marc Delrez, 'Antipodean Dialogue: R. Stow and D. Malouf', in Geoffrey Davis and Hena Maes-Jelinek (eds.), Crisis and Creativity in the Nem Literatures in English (Amsterdam: Rodopi, I990), pp. 29I-307; and the essay by Ashcroft cited in the previous footnote.

24 D. H. Lawrence, Kangaroo (Harmondsworth: Penguin, I950), p. 26.

25 At a talk at the South Bank Centre in London some years ago, I asked Malouf whether he was 'responding' to the English writer's view of Australia; he replied that he had not been aware of this passage.

26 See, for example, Neilsen, Griffiths, Martin in note 23 above; Andrew Taylor, " "The Bread of Times to Come": Body and Landscape in David Malouf's Fiction', World Literature Today 74, 4 (2000), 715-23; Amanda Nettelbeck, 'Rewriting an Explorer's Mythology: The Narration of Space in David Malouf's Work', in Nettelbeck (ed.), Provisional Maps: Critical Essays on David Malouf (Nedlands: Centre for Studies in Australian Literature, The University of Western Australia, I994), pp. IоI-I6.

27 André Dommergues discusses the analogies between Itard's and Malouf's texts in 'Traditions and Dream in David Malouf's An Imaginary Life', Commonmealth Essays and Studies I0, I (1987), 6I-7. Jean Marc Gaspard Itard's own account of his attempts to educate Victor was published in De l'éducation d'un Homme sauvage, et des premiers développements physiques et moraux du jeune sauvage de l'Aveyron (Paris, I8or), translated into English in An Historical Account of the Discovery and Education of a Savage Man, or of the First Development, Physical and Moral, of the Young Savage Caught in the Woods Near Aveyron in the Year 1798 (London, Philips, I802), most recently republished in Lucien Malson, Les Enfants sauvages (Paris: Union générale d'éditions, I964), English translation: Wolf Children. The Wild Boy of Aveyron, by Fean Itard (London: NLB, I972).

28 Michel de Montaigne, 'On the Cannibals', in The Complete Essays (London: Penguin, I99I), pp. 228-4I.

29 Cf., for example, Saint Augustine, Confessions (Harmondsworth: Penguin, I96r), Book I. For a discussion of the role of language in autobiography see, for 
example, Eakin, who, in the chapter 'Self-Invention in Autobiography. The Moment of Language', observes that 'much of the controversy about the ontological status of the self in autobiography has tended to polarize into a selfbefore-language or a language-before-self set of positions, whereas the most promising contemporary treatments suggest that the self and language are mutually implicated in a single, interdependent system of symbolic behavior'. Paul John Eakin, Fictions in Autobiography: Studies in the Art of Self-Invention (Princeton: Princeton University Press, I985), pp. I9I-2.

30 See Lawrence Lipking, 'Frankenstein, the True Story; or, Rousseau Judges JeanJacques', in Mary Shelley's Frankenstein: The I8I8 Text, Contexts, NineteenthCentury Responses, Modern Criticism, ed. by J. Paul Hunter (New York and London: Norton, I966), pp. 3 ${ }^{\text {I }}{ }^{-3}$ I . References to Shelley's text (hereafter $F$ ) will be to this edition. In this context it is worth noting that Malouf has also written the libretto for Richard Meale's opera adaptation of Frankenstein, Mer de Glace (I99I).

3 I Cf., for example, Rousseau's Discourse on the Origins and Foundations of Inequality Among Mankind, in The Social Contract and The First and Second Discourses, ed. by Susan Dunn (New Haven: Yale University Press, 2002). See in particular pp. 99-104 on the development of language; this discussion concludes with the question - which Rousseau declares too complex to answer in detail and definitively - 'What was the more necessary, society already formed to invent languages, or languages already invented to form society?' (p. I04). 